\title{
Physicochemical Characteristics of River Water Downstream of a Large Tropical Hydroelectric Dam
}

\author{
Teck-Yee Ling, ${ }^{1}$ Chen-Lin Soo, ${ }^{1}$ Teresa Lee-Eng Heng, ${ }^{1}$ \\ Lee Nyanti, ${ }^{2}$ Siong-Fong Sim, ${ }^{1}$ and Jongkar Grinang ${ }^{3}$ \\ ${ }^{1}$ Department of Chemistry, Faculty of Resource Science and Technology, Universiti Malaysia Sarawak, \\ 94300 Kota Samarahan, Sarawak, Malaysia \\ ${ }^{2}$ Department of Aquatic Science, Faculty of Resource Science and Technology, Universiti Malaysia Sarawak, \\ 94300 Kota Samarahan, Sarawak, Malaysia \\ ${ }^{3}$ Institute of Biodiversity and Environmental Conservation, Universiti Malaysia Sarawak, 94300 Kota Samarahan, Sarawak, Malaysia
}

Correspondence should be addressed to Teck-Yee Ling; teckyee60@gmail.com

Received 21 April 2016; Accepted 4 August 2016

Academic Editor: Samuel B. Dampare

Copyright (C) 2016 Teck-Yee Ling et al. This is an open access article distributed under the Creative Commons Attribution License, which permits unrestricted use, distribution, and reproduction in any medium, provided the original work is properly cited.

Water quality in the downstream river of a hydroelectric dam may be affected by the structural design and operation. To date, little is known about the water quality downstream of the largest dam in Malaysia, the Bakun hydroelectric dam. Therefore, the objective of the study was to determine the water quality downstream of the dam when the spillway was closed and when it was opened. Results of the study indicate that the dam plays a significant role in regulating the water quality downstream of it. When the spillway was closed, $\mathrm{pH}$ and oxygen were lower in the river where $\mathrm{DO}$ was below $5 \mathrm{mg} / \mathrm{L}$. When the spillway was opened, the water quality improved in terms of oxygen content $(>8.0 \mathrm{mg} / \mathrm{L})$, total sulphide (TS), and chemical oxygen demand (COD) but deteriorated in terms of five-day biochemical oxygen demand $\left(\mathrm{BOD}_{5}\right)$, total ammonia nitrogen (TAN), and total phosphorus (TP). Additionally, the intensity of the impacts, particularly $\mathrm{BOD}_{5}, \mathrm{COD}$, and TAN, shows a declining trend as distance from the dam increases. This study shows that impacts on the water quality extend to a distance of $32 \mathrm{~km}$ from the dam particularly turbidity and $\mathrm{DO}$ and opening the spillway changes the water quality significantly.

\section{Introduction}

Dam and reservoir construction in river courses are booming all over the world for hydropower generation, flood control, irrigation, and water supply. In Malaysia, there are about 80 dams that have been built where majority of the dams are for water supply in most of the states of Peninsular Malaysia including Sabah while hydropower dams are the most common in the states of Sarawak and Perak [1]. Among them, Sarawak owns the largest hydropower project in Malaysia with an installed capacity of 2,400MW of electricity and the second tallest concrete rock filled dams $(205 \mathrm{~m})$ in the world which is the Bakun hydroelectric dam. The dam is situated on the Balui River, a tributary of the longest river in Malaysia, the Rajang River. It is impounded in 2010 and reached its full supply level in 2012 where the flooded area is over $695 \mathrm{~km}^{2}$ $[2,3]$.
The physicochemical parameters of the Bakun dam reservoir have been studied in pre- and postimpoundment condition $[2,3]$. However, studies on the tropical regulated downstream river of the dam are limited though it is also subjected to major environmental impacts ranging from downstream morphology to biodiversity of the ecosystem [4-10]. Downstream impacts of the dam can sometimes extend up to a distance of hundred kilometers from the dam site [11], although the intensity of the impacts tends to decline with increasing distance from the dam site [12, 13]. Dams can change downstream hydrology by altering the flow pattern which subsequently change the water quality of the downstream river [14-19]. Thus, it is of scientific importance to investigate and evaluate the water quality changes induced by dam construction and operation.

Despite the substantial size of the Bakun hydroelectric dam and its potential impact on the downstream river, the 


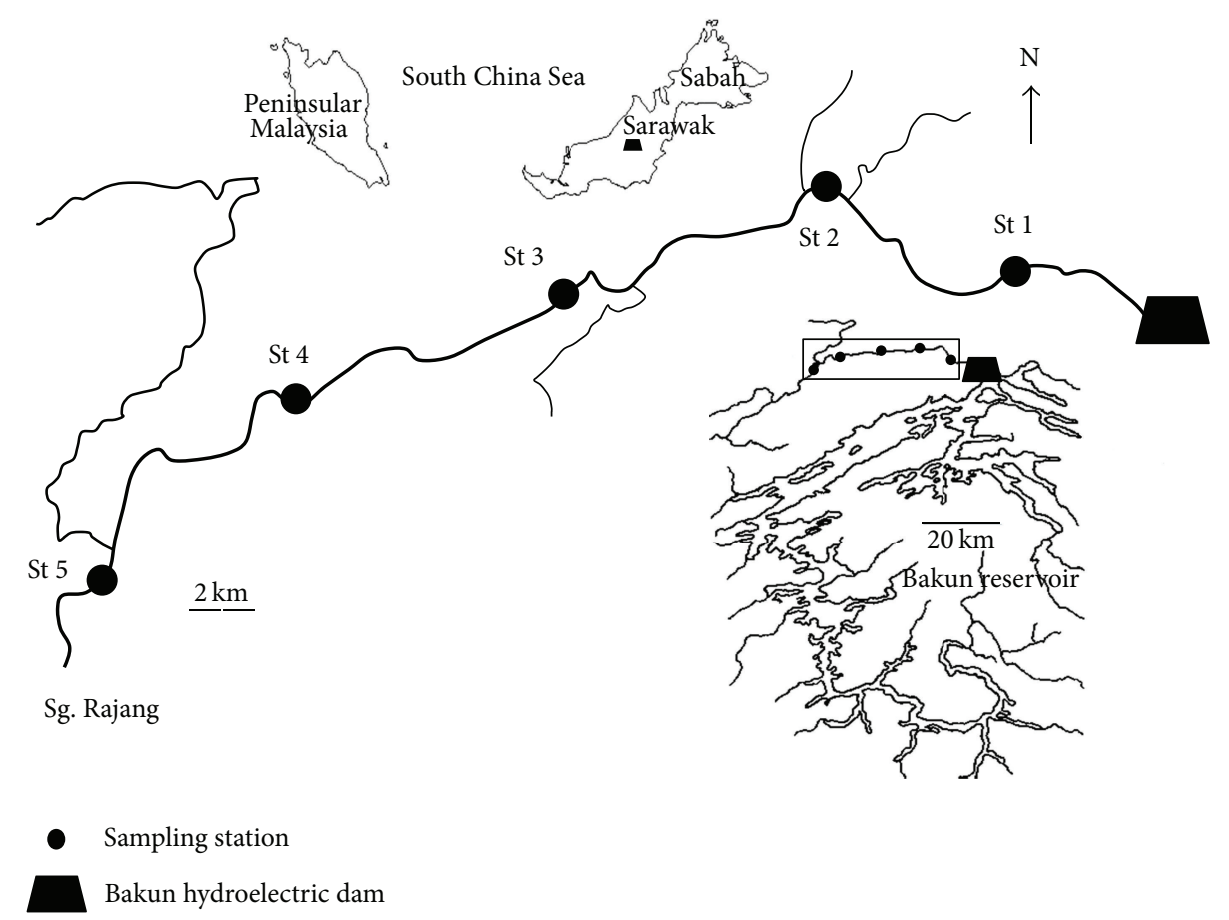

FIGURE 1: Location of the sampling stations along the downstream river, Balui River, of the Bakun hydroelectric dam in the present study in the state of Sarawak, Malaysia.

water quality of its downstream river is scarcely known. Recently, a study had shown that higher concentration of Fe and Mn was detected in downstream water of the Bakun hydroelectric reservoir with significant longitudinal variation [20]. Structural difference between Bakun dam and other big tropical dams in the world may result in differences in downstream water quality. Therefore, the present study was initiated to assess the water quality of the downstream river of the Bakun hydroelectric dam when the spillway was closed and when it was opened. The findings would provide valuable information for the operation and management of the dam for the benefit of downstream aquatic organisms.

\section{Material and Methods}

2.1. Study Area and Sampling Stations. The present study was conducted at the Balui River, downstream Bakun hydroelectric dam in Sarawak, Malaysia, from Long Baagu to below Belaga town (Figure 1) when the electrical power generation was ongoing. The river received water discharged from the reservoir of the dam after the water passed through the turbines. Intake for power generation was at about $10 \mathrm{~m}$ depth from the surface. A total of five stations were selected along the downstream river up to a distance of $32.1 \mathrm{~km}$ from the dam (Table 1). The first sampling was conducted on 6 November 2013 when the spillway was closed. The second sampling was conducted in 26 February 2014 where additional water was discharged from the spillway with intake at a depth of $\sim 15 \mathrm{~m}$. At the end of the spillway, the water hits the concrete barrier before entering downstream Balui River. The downstream river flow during second trip when additional water was discharged from the spillway of the dam was faster than first trip. It rained in the morning during the first trip whereas no rain was recorded for two weeks before the second trip.

2.2. Field Collection and Laboratory Analysis. Both in situ and ex situ parameters were studied. $\mathrm{pH}$ and dissolved oxygen (DO) were measured using an Orion 3-star Plus Portable pH meter and a Milwaukee DO meter, respectively. Turbidity was measured using a YSI 6820 Multiparameter Sonde and a Hanna Instrument in the first and second trips, respectively. Water samples were collected in triplicate for the analysis of five-day biochemical oxygen demand $\left(\mathrm{BOD}_{5}\right)$, chemical oxygen demand (COD), total ammonia nitrogen (TAN), total phosphorus (TP), and total sulphide (TS). All sampling bottles were acid-washed, cleaned, and dried before use. Water samples were preserved using zinc acetate for TS analysis whereas water samples were acidified to $\mathrm{pH}<2$ for TAN and TP analysis. All water samples were placed in an ice box and transported to the laboratory for further analysis [21].

Prior to the analysis, the triplicate water samples were composited. All the analyses were conducted according to standard methods $[21,22]$. For $\mathrm{BOD}_{5}$ analysis, it began in the field. As DO values in the first trip were low, water was aerated by shaking in a $2 \mathrm{~L}$ bottle before initial DO was measured. Final DO was measured after incubation of the sample in the dark at $20^{\circ} \mathrm{C}$. Subsequently, $\mathrm{BOD}_{5}$ was calculated using standard methods. COD was determined by closed reflux titrimetric method [21] where FAS concentration used was 
TABLE 1: The details of the sampling location and sampling regime in the present study.

\begin{tabular}{|c|c|c|c|c|c|c|}
\hline \multirow{2}{*}{$\begin{array}{l}\text { Station (distance } \\
\text { from Bakun dam) }\end{array}$} & \multirow{2}{*}{ GPS coordinate } & \multirow{2}{*}{ Description } & \multicolumn{2}{|c|}{ 1st trip (6.11.2013) } & \multicolumn{2}{|c|}{ 2nd trip (26.2.2014) } \\
\hline & & & Time & Depth (m) & Time & Depth $(\mathrm{m})$ \\
\hline St $1(4.3 \mathrm{~km})$ & $\mathrm{N} 02^{\circ} 46^{\prime} 21.8^{\prime \prime} \mathrm{E} 114^{\circ} 01^{\prime} 41.6^{\prime \prime}$ & Long Baagu & $6.20 \mathrm{pm}$ & 13.2 & $3.00 \mathrm{pm}$ & 10.7 \\
\hline St $2(9.9 \mathrm{~km})$ & $\mathrm{N} 02^{\circ} 47^{\prime} 02.0^{\prime \prime} \mathrm{E} 113^{\circ} 58^{\prime} 43.2^{\prime \prime}$ & $\begin{array}{l}\text { Right above Metjawah } \\
\text { (Lubok Metjawah ) }\end{array}$ & $5.30 \mathrm{pm}$ & 9.2 & $2.10 \mathrm{pm}$ & 5.4 \\
\hline St $3(17.5 \mathrm{~km})$ & $\mathrm{N} 02^{\circ} 46^{\prime} 05.2^{\prime \prime} \mathrm{E} 113^{\circ} 54^{\prime} 23.0^{\prime \prime}$ & $\begin{array}{l}\text { Right below longhouse } \\
\text { Lahanan Long Semuang }\end{array}$ & $4.00 \mathrm{pm}$ & 4.5 & $12.45 \mathrm{pm}$ & 4.1 \\
\hline St $4(24.9 \mathrm{~km})$ & $\mathrm{N} 02^{\circ} 44^{\prime} 34.5^{\prime \prime} \mathrm{E}_{113^{\circ}} 50^{\prime} 21.8^{\prime \prime}$ & $\begin{array}{l}\text { Right above longhouse } \\
\text { Kejaman Neh }\end{array}$ & $3.00 \mathrm{pm}$ & 2.1 & $12.05 \mathrm{pm}$ & 5.9 \\
\hline St $5(32.1 \mathrm{~km})$ & $\mathrm{N} 02^{\circ} 42^{\prime} 02.9^{\prime \prime} \mathrm{E} 13^{\circ} 46^{\prime} 46.3^{\prime \prime}$ & Below Belaga Town & $1.30 \mathrm{pm}$ & 7.9 & $11.05 \mathrm{am}$ & 10.0 \\
\hline
\end{tabular}

$0.025 \mathrm{M}$. TAN was determined by Nessler's method after distillation [22]. TP was determined by ascorbic acid method after sulfuric-nitric acid digestion of samples [21]. TS was analyzed using the methylene blue method [22]. A calibration curve was prepared for each chemical analysis. Blank and standard solutions were treated in the same way as the sample.

2.3. Statistical Analysis. When data were tested for normality and equal variance with Shapiro-Wilk test and Levene's test, respectively, it was found to be significantly different from normal distribution and unequal in variances. Thus, nonparametric tests were used in the subsequent statistical analyses. To determine if there was any significant difference in the results between the five sampling stations of each sampling trip Kruskal-Wallis test was used. Wilcoxon Signrank test was used to compare the water quality of the downstream river between opened and closed spillway. All the statistical analyses were conducted by using SPSS Version 22 .

\section{Results and Discussion}

Figure 2 shows that the water discharged from the Bakun hydroelectric reservoir has a great impact on the in situ water quality at the downstream river. Low $\mathrm{pH}$ value was observed at stations near to the dam which is most likely due to the low $\mathrm{pH}$ water of the reservoir from a depth of between 10 and $15 \mathrm{~m}$ that was released into the downstream river after passing through the turbines [3]. However, the $\mathrm{pH}$ value steadily increased from $6.0 \pm 0.0$ to $7.7 \pm 0.0$ along the downstream river due to the dilution from the tributaries in the first sampling. However, when water was also discharged from the opened spillway in the second sampling, the $\mathrm{pH}$ value is relatively constant along the downstream river, ranging from $6.1 \pm 0.0$ to $6.2 \pm 0.0$. In addition to the impact of the high volume of low $\mathrm{pH}$ reservoir water, no precipitation for two weeks before the second sampling could also contribute to the low $\mathrm{pH}$ value up to a distance of $32 \mathrm{~km}$ from the dam in the present study. Overall, the $\mathrm{pH}$ value of the downstream river is mostly classified as Class II according to National Water Quality Standard (NWQS) for Malaysia except stations 4 and 5 in the first trip which are classified as Class I [23].

The mean value of DO along the downstream river was $4.3 \mathrm{mg} / \mathrm{L}$ and $9.2 \mathrm{mg} / \mathrm{L}$ when reservoir water is discharged
TABLE 2: Mean difference in water quality parameters between closed and opened spillway when the Bakun hydroelectric dam is in operation $(N=5)$.

\begin{tabular}{lcc}
\hline Parameters & Mean difference & $p$ value \\
\hline $\mathrm{pH}$ & 0.4 & 0.057 \\
$\mathrm{DO}, \mathrm{mg} / \mathrm{L}$ & -4.8 & $\mathbf{0 . 0 0 1}$ \\
Turbidity, NTU & -19.0 & $\mathbf{0 . 0 0 1}$ \\
$\mathrm{TS}, \mathrm{mg} / \mathrm{L}$ & 1.3 & $\mathbf{0 . 0 1 9}$ \\
$\mathrm{BOD}_{5}, \mathrm{mg} / \mathrm{L}$ & -0.5 & $\mathbf{0 . 0 2 8}$ \\
$\mathrm{COD}, \mathrm{mg} / \mathrm{L}$ & 26.4 & $\mathbf{0 . 0 0 1}$ \\
$\mathrm{TAN}, \mathrm{mg} / \mathrm{L}$ & -0.065 & $\mathbf{0 . 0 0 1}$ \\
$\mathrm{TP}, \mu \mathrm{g} / \mathrm{L}$ & -114.7 & $\mathbf{0 . 0 0 1}$ \\
\hline
\end{tabular}

Positive value of mean difference indicates water quality parameter was higher during closed spillway, whereas negative value indicates water quality parameter was higher during opened spillway of the Bakun hydroelectric dam. The significant difference at $p$ value $\leq 0.05$ was indicated in bold.

with the spillway closed and opened, respectively. According to the NWQS, DO is classified as Class III along the downstream river when water is discharged from the dam during power generation with the spillway closed. The DO content improved considerably when the spillway was open where the DO is classified as Class I. Table 2 shows that the DO value along the downstream river is significantly higher when additional water was discharged from the spillway of the dam ( $p$ value $\leq 0.05)$ but decreased steadily along the downstream river as illustrated by Figure 2. On the other hand, when spillway was closed and the only water was discharged through the turbines, DO value is the lowest at station 1 which is the nearest station to the dam but steadily increased along the downstream river indicating the DO content was first impacted by the low DO content from the reservoir but was then diluted by river water with higher DO content along the downstream river. Despite the dilution along the downstream river, station 5 which is the furthest station from the dam still showed DO of less than $5 \mathrm{mg} / \mathrm{L}$. Besides the low DO content in the downstream river that raises environmental health concerns, the high $\mathrm{DO}$ when the water is discharged from the spillway may also pose ecological risks to the downstream river. The high oxygen level caused by the rapid aeration when water plunged from the spillway hitting the barrier may cause the total dissolved gas (TDG) 


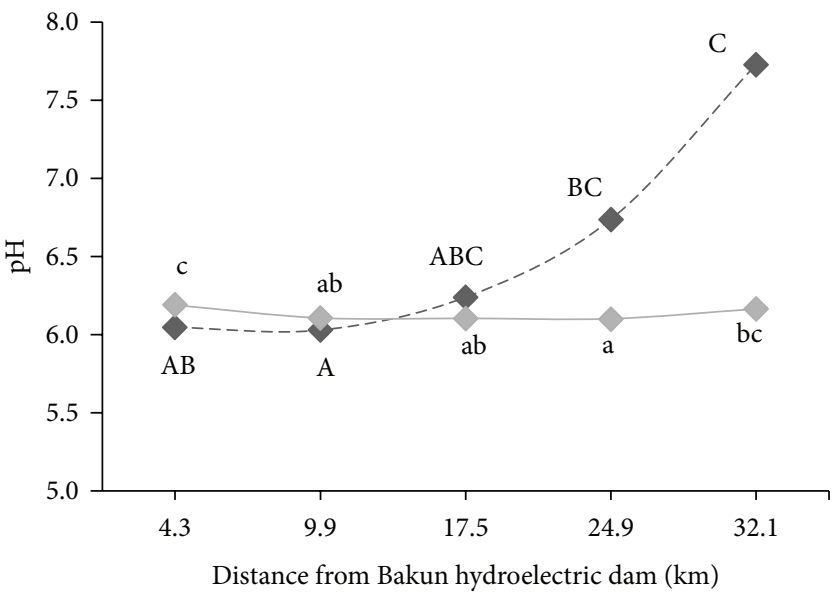

Water discharged during power generation Water discharged from spillway

(a)

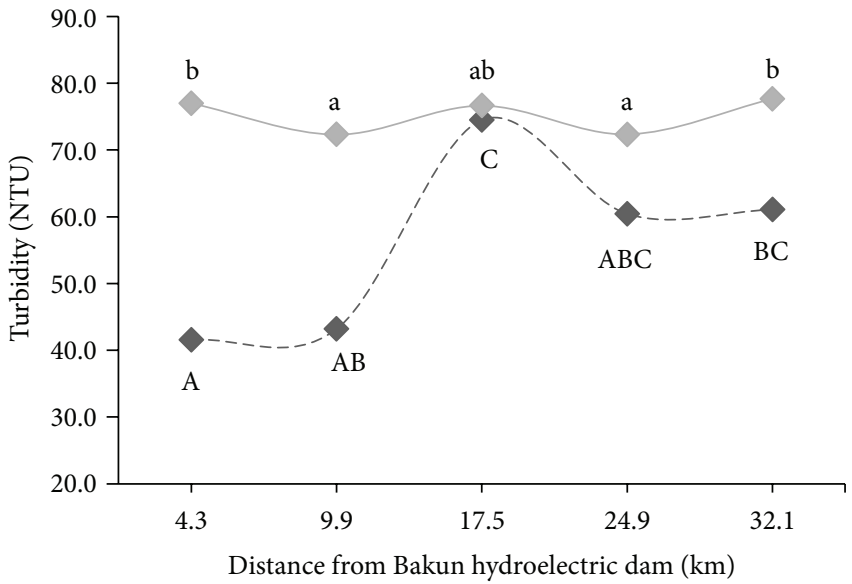

Water discharged during power generation Water discharged from spillway

(c)

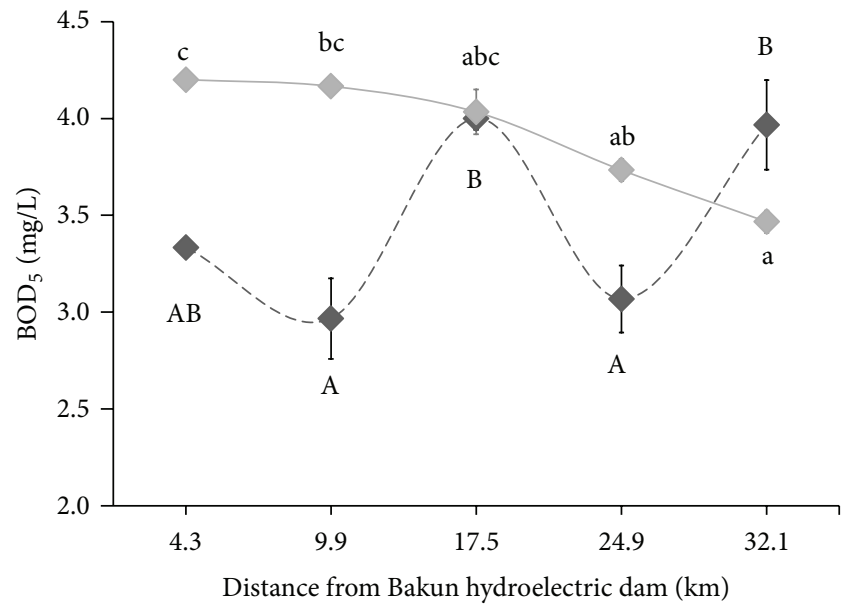

Water discharged during power generation Water discharged from spillway

(e)

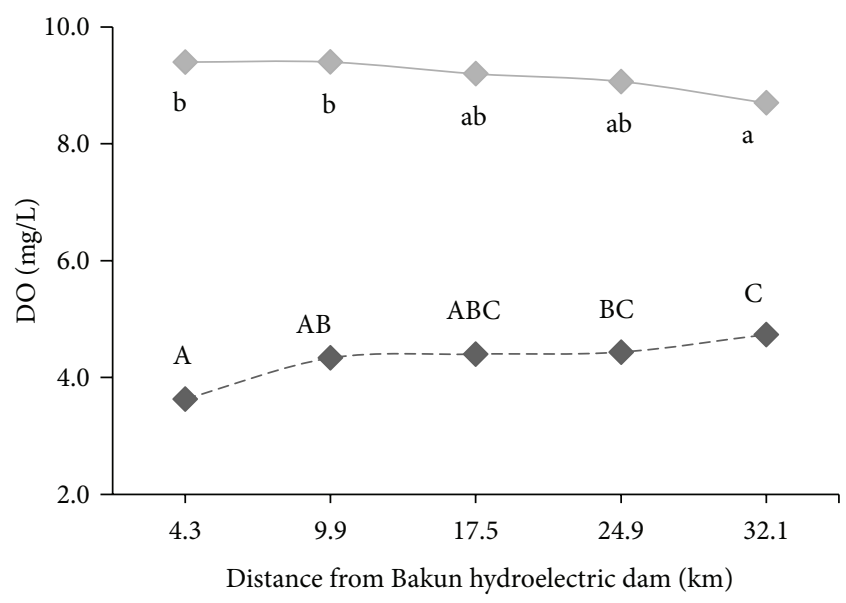

Water discharged during power generation Water discharged from spillway

(b)

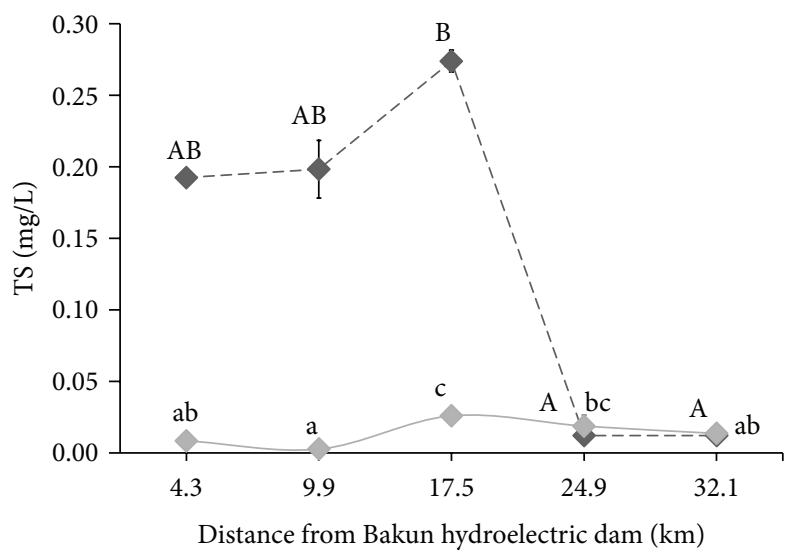

Water discharged during power generation Water discharged from spillway

(d)

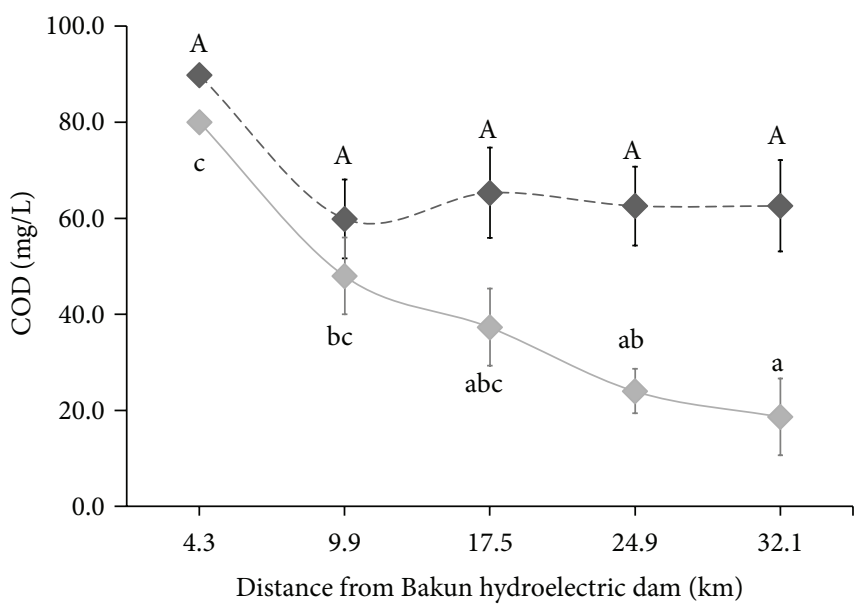

Water discharged during power generation Water discharged from spillway

(f)

Figure 2: Continued. 


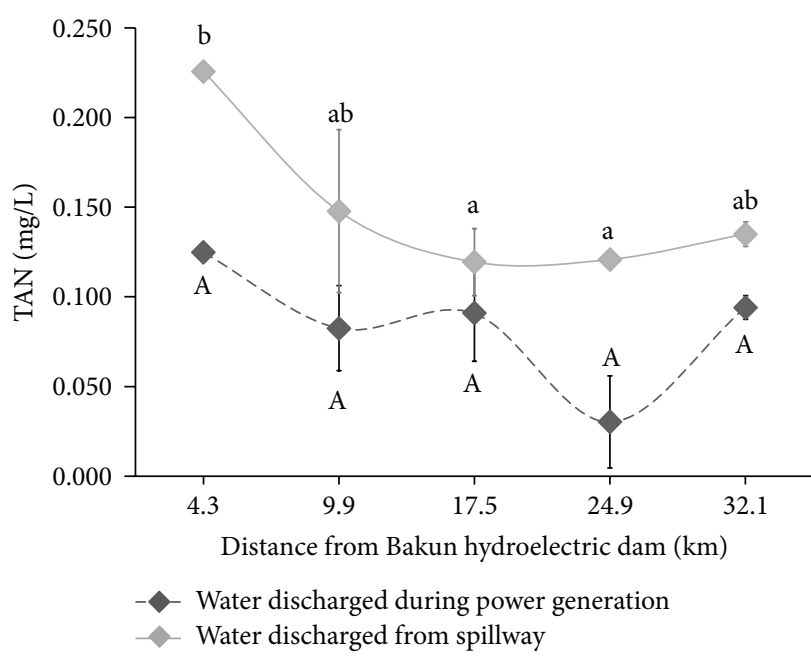

(g)

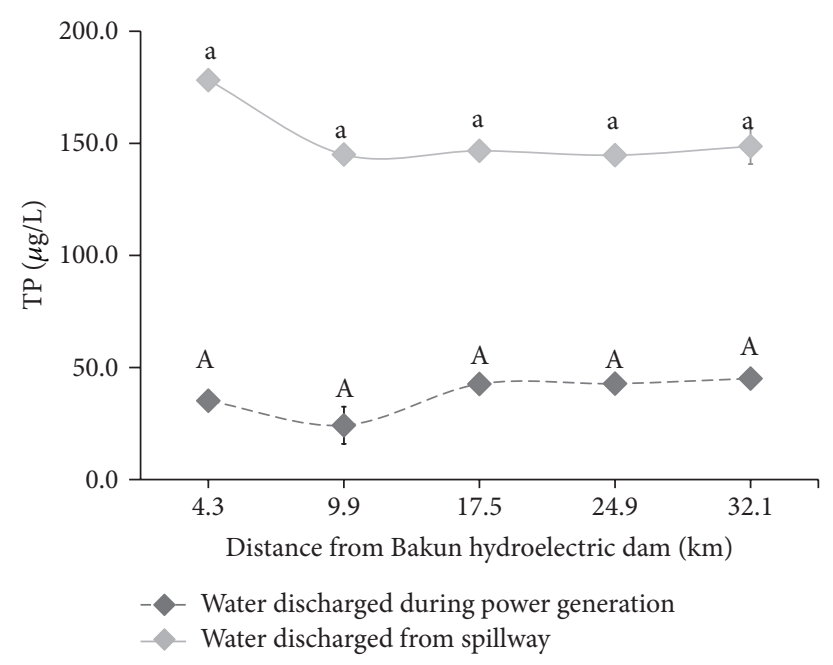

(h)

FIGURE 2: In situ and ex situ water quality parameters of (a) pH, (b) DO, (c), turbidity, (d) TS, (e) BOD 5 , (f) COD, (g), TAN, and (h) TP at stations of downstream Bakun hydroelectric dam when the spillway was closed (dash line) and when it is opened (solid line) when the dam is in operation. Different letters indicate significant difference at $p$ value $\leq 0.05$ along the downstream river (uppercase-spillway closed; lowercase-spillway opened).

supersaturation in the downstream water which could lead to bubble disease on fish living downstream of dams [17, 24, 25].

The turbidity value $(\approx 40 \mathrm{NTU})$ at station 1 when water is discharged from the dam during power generation with closed spillway is similar to the turbidity value of the Bakun reservoir which ranged from 22 to 40 NTU at a depth of 10$15 \mathrm{~m}$ [3]. The highest turbidity value $(74.5 \pm 0.6 \mathrm{NTU})$ was observed at station 3 and the high turbidity value at stations 4 and 5 (>60 NTU) indicating the possible anthropogenic influences of suspended solids from adjacent area besides the impact of the dam. Turbidity value increased significantly $(p$ value $\leq 0.05)$ when the spillway was opened with a mean value of $75.2 \mathrm{mg} / \mathrm{L}$. The high turbidity value had extended up to a distance of $32 \mathrm{~km}$ from the dam in the present study. When water is discharged from the spillway in addition to turbine outflow, resuspension of deposited sediments under high flow rate increases the suspended solids downstream. Besides the impacts of the reservoir water discharged from the spillway, the high turbidity value could also be due to the low dilution from the tributaries along the downstream river as there was no precipitation for two weeks before the second sampling was conducted. Overall, most of the turbidity value at both trips ( $>50$ NTU) had exceeded the Class II of NWQS for Malaysia [23] except stations 1 and 2 in the first sampling.

When water is discharged from the dam during power generation when spillway was closed, TS was very high at stations 1,2 , and $3(\approx 0.22 \mathrm{mg} / \mathrm{L})$ up to a distance of $17.5 \mathrm{~km}$ from the dam. The high TS concentration at the downstream river near to the dam indicates that it is most likely due to the reservoir water that contains high TS concentration [26]. Strong rotten egg smell indicating the presence of hydrogen sulphide had been detected at Bakun reservoir during the filling phase [2]. However, TS concentration was found much lower at stations 4 and 5 most likely due to degassing and oxidation of hydrogen sulphide when the anaerobic water was aerated [27]. When the spillway is opened, the water was aerated by the plunge and impact on the concrete wall resulting in degassing and oxidation of hydrogen sulphide and this water diluted the higher sulphide water from the turbine outflow leading to significantly ( $p$ value $\leq 0.05$ ) lower TS along the downstream river. The mean TS concentration along the downstream river decreased from $0.14 \mathrm{mg} / \mathrm{L}$ to $0.01 \mathrm{mg} / \mathrm{L}$, where the TS value changes from noncompliance to compliance with the $0.05 \mathrm{mg} / \mathrm{L}$ standard [23]. The highest concentration of TS in both samples was found at station 3 indicating that station 3 which is located below the longhouse may have contributed substantial TS besides the reservoir water.

The $\mathrm{BOD}_{5}$ concentration fluctuated along the downstream river with the highest value located at stations 3 and $5(\approx 4.0 \mathrm{mg} / \mathrm{L})$ when the spillway was closed. $\mathrm{BOD}_{5}$ concentration at the two stations is also significantly higher $(p$ value $\leq 0.05)$ than the $\mathrm{BOD}_{5}$ concentration at stations $2(3.0 \pm 0.1 \mathrm{mg} / \mathrm{L})$ and $4(3.1 \pm 0.2 \mathrm{mg} / \mathrm{L})$. The higher concentration of $\mathrm{BOD}_{5}$ at the two stations indicates that high $\mathrm{BOD}_{5}$ concentration is most likely attributed to the domestic discharge and runoff as stations 3 and 5 were located below longhouses and Belaga town, respectively. When the spillway was opened, the $\mathrm{BOD}_{5}$ concentration increased significantly ( $p$ value $\leq 0.05$ ) compared to when closed but significantly decreased from $4.2 \pm 0.0 \mathrm{mg} / \mathrm{L}$ to $3.5 \pm 0.1 \mathrm{mg} / \mathrm{L}$ ( $p$ value $\leq 0.05$ ) along the downstream river as distance increases as shown in Figure 2. The $\mathrm{BOD}_{5}$ concentration along the downstream river was classified as Class III at all stations except station 2 (Class II) in the first sampling.

Figure 2 illustrates that the highest COD concentration ( $\approx 85 \mathrm{mg} / \mathrm{L}$ ) was observed at station 1 which is the nearest station to the dam in both trips. The value lies between the 
COD concentrations near to the Bakun dam in the reservoir at a depth between $15 \mathrm{~m}$ and $30 \mathrm{~m}$ [3]. In the present study, COD concentration decreased significantly ( $p$ value $\leq 0.05$ ) from $80.0 \pm 8.0 \mathrm{mg} / \mathrm{L}$ to $18.7 \pm 4.6 \mathrm{mg} / \mathrm{L}$ along the downstream river when additional water was discharged from the spillway. The classification of COD shows improvement with increasing distance from the dam, that is, from Class IV to Class II. Besides, the mean COD concentration was also significantly lower ( $p$ value $\leq 0.05$ ) when the spillway was opened compared to closed spillway. When the spillway was closed, COD concentration was not significantly different ( $p$ value $>0.05$ ) along the downstream river, although the COD concentration decreased from $90 \mathrm{mg} / \mathrm{L}$ at station 1 to $63 \mathrm{mg} / \mathrm{L}$ at the subsequent stations as illustrated in Figure 2. When the spillway was opened, the high volume of reservoir water was aerated resulting in high DO in the river which lowered the COD concentration substantially along the downstream river.

The TAN concentration ranged from $0.030 \pm 0.007 \mathrm{mg} / \mathrm{L}$ to $0.125 \pm 0.024 \mathrm{mg} / \mathrm{L}$ and $0.119 \pm 0.002 \mathrm{mg} / \mathrm{L}$ to $0.226 \pm$ $0.045 \mathrm{mg} / \mathrm{L}$ when the spillway was closed and opened, respectively. Similar to COD concentration, the highest value of TAN was observed at station 1 and the values are comparable to the TAN concentration in the Bakun reservoir near to the Bakun dam at a depth of $15 \mathrm{~m}$ and $30 \mathrm{~m}$ which was reported to be $0.14 \mathrm{mg} / \mathrm{L}$ and $0.35 \mathrm{mg} / \mathrm{L}$, respectively [3]. In the present study, the TAN concentration when the spillway was closed is similar to the reservoir TAN concentration near to the Bakun dam at a depth of $15 \mathrm{~m}$ whereas TAN concentration when the spillway was opened lies between $15 \mathrm{~m}$ and $30 \mathrm{~m}$ depths of the reservoir TAN concentration. No significant difference of TAN concentration ( $p$ value $>$ 0.05) was observed along the downstream river when the spillway was closed; but TAN shows sign of decrease along the downstream river when the spillway was opened where TAN concentrations at stations 3 and 4 were significantly lower ( $p$ value $\leq 0.05$ ) than TAN concentration at station 1 . The mean TAN concentration increased significantly $(p$ value $\leq 0.05)$ when water was discharged from the spillway $(0.15 \mathrm{mg} / \mathrm{L})$ compared to the dam $(0.085 \mathrm{mg} / \mathrm{L})$ and the classification of TAN changed from Class I to Class II at all stations except station 1 where it was classified as Class II at both samples. The result indicates that reservoir water and the dam operation greatly influence the TAN concentration in the downstream river of the dam.

Figure 2 shows that no significant difference of TP ( $p$ value $>0.05$ ) was observed as we moved along the downstream river stations in both opened and closed spillway conditions. However, TP concentrations were higher when spillway was opened, and values ranged from $24.2 \pm 0.6$ to $45.1 \pm 5.0 \mu \mathrm{g} / \mathrm{L}$ and $144.7 \pm 7.9$ to $178.2 \pm 2.4 \mu \mathrm{g} / \mathrm{L}$ when the spillway was closed and opened, respectively. The mean value of TP increased significantly ( $p$ value $\leq 0.05$ ) from $38 \mu \mathrm{g} / \mathrm{L}$ to $152.7 \mu \mathrm{g} / \mathrm{L}$ when the spillway was opened compared to closed spillway (Table 2). The result indicates that reservoir water contributes substantial TP to the downstream river and the impact extended up to a distance of $32 \mathrm{~km}$ in the present study. Nevertheless, TP concentration along the downstream river is classified as Class I for both trips indicating that the
TP concentration is still of acceptable standard according to Malaysia National Water Quality Standard [23].

\section{Conclusions}

The present study indicates that Bakun hydroelectric dam plays a significant role in regulating the downstream water quality. The downstream river was low in $\mathrm{pH}$ and $\mathrm{DO}$ but high in turbidity, TS, $\mathrm{BOD}_{5}, \mathrm{COD}, \mathrm{TAN}$, and TP. Nevertheless, the $\mathrm{pH}$ and $\mathrm{DO}$ gradually increased along the downstream river. Opening the spillway increased the mean DO, turbidity, $\mathrm{BOD}_{5}$, TAN, and TP significantly whereas it decreases mean TS and COD significantly in the downstream river. The low $\mathrm{pH}$ and high turbidity and TP remained along the downstream river up to a distance of $32 \mathrm{~km}$ from the dam whereas the $\mathrm{DO}, \mathrm{BOD}_{5}$, and COD decreased significantly with increasing distance from the dam. Besides the influence of the reservoir water, the water quality of the downstream river was also subjected to anthropogenic activities particularly at station 3 and station 5 which are located below longhouses and township. High turbidity, TS, and $\mathrm{BOD}_{5}$ were observed at station 3 whereas high turbidity and $\mathrm{BOD}_{5}$ were observed at station 5. Even though opening the spillway increased DO and reduced toxic sulphide in the downstream river, further studies need to be conducted to see the effect of the total dissolved gas supersaturated water on the aquatic organisms especially fish in the area.

\section{Competing Interests}

The authors declare that there are no competing interests regarding the publication of this paper.

\section{Acknowledgments}

The authors appreciate the financial support provided by the Ministry of Higher Education through Grant no. FRGS/STWN01(04)/991/2013(32) and the facilities provided by Universiti Malaysia Sarawak.

\section{References}

[1] A. M. Latifah and L. Met, "An ecological evaluation approach for dam project development in Malaysia," Life Science Journal, vol. 11, no. 7, pp. 225-237, 2014.

[2] L. Nyanti, T. Y. Ling, and J. Grinang, "Physico-chemical characteristics in the filling phase of Bakun hydroelectric reservoir, Sarawak, Malaysia," International Journal of Applied Science and Technology, vol. 2, no. 6, pp. 92-101, 2012.

[3] T. Y. Ling, L. Nyanti, T. Muan, J. Grinang, S. F. Sim, and A. Mujahid, "Physicochemical parameters of bakun reservoir in Belaga, Sarawak, Malaysia, 13 months after reaching full supply level," Sains Malaysiana, vol. 45, no. 2, pp. 157-166, 2016.

[4] Y. Yi, Z. Yang, and S. Zhang, "Ecological influence of dam construction and river-lake connectivity on migration fish habitat in the Yangtze River basin, China," Procedia Environmental Sciences, vol. 2, no. 5, pp. 1942-1954, 2010. 
[5] M. W. Beck, A. H. Claassen, and P. J. Hundt, "Environmental and livelihood impacts of dams: common lessons across development gradients that challenge sustainability," International Journal of River Basin Management, vol. 10, no. 1, pp. 73-92, 2012.

[6] X. Li, S. Dong, Q. Zhao, and S. Liu, "Impacts of Manwan Dam construction on aquatic habitat and community in Middle Reach of Lancang River," Procedia Environmental Sciences, vol. 2, no. 5, pp. 706-712, 2010.

[7] W. Wildi, "Environmental hazards of dams and reservoirs," Near Curriculum in Natural Environmental Science, vol. 88, pp. 187197, 2010.

[8] Q. G. Wang, Y. H. Du, Y. Su, and K. Q. Chen, "Environmental impact post-assessment of dam and reservoir projects: a review," Procedia Environmental Sciences, vol. 13, pp. 1439-1443, 2012.

[9] P. McCully, "Rivers no more: the environmental effects of dams," in Silenced Rivers: The Ecology and Politics of Large Dams, P. McCully, Ed., pp. 29-64, Zed Books, London, UK, 1996.

[10] Q. Lin, "Influence of dams on river ecosystem and its countermeasures," Journal of Water Resource and Protection, vol. 03, no. 01, pp. 60-66, 2011.

[11] R. Preece, Cold Water Pollution below Dams in New South Wales, Department of Infrastructure, Planning and Natural Resources, Sydney, Australia, 2004.

[12] Q. Zhao, S. Liu, L. Deng, S. Dong, Z. Yang, and Q. Liu, "Determining the influencing distance of dam construction and reservoir impoundment on land use: a case study of Manwan Dam, Lancang River," Ecological Engineering, vol. 53, pp. 235242, 2013

[13] N. D. Gillett, Y. Pan, J. Eli Asarian, and J. Kann, "Spatial and temporal variability of river periphyton below a hypereutrophic lake and a series of dams," Science of The Total Environment, vol. 541, pp. 1382-1392, 2016.

[14] Y. Zhang, J. Xia, T. Liang, and Q. Shao, "Impact of water projects on river flow regimes and water quality in Huai River Basin," Water Resources Management, vol. 24, no. 5, pp. 889-908, 2010.

[15] L. Feng, X. Sun, and X. Zhu, "Impact of floodgates operation on water environment using one-dimensional modelling system in river network of Wuxi city, China," Ecological Engineering, vol. 91, pp. 173-182, 2016.

[16] Q. Zhao, S. Liu, L. Deng et al., "Landscape change and hydrologic alteration associated with dam construction," International Journal of Applied Earth Observation and Geoinformation, vol. 16, no. 1, pp. 17-26, 2012.

[17] H. Guo, Q. Hu, Q. Zhang, and S. Feng, "Effects of the Three Gorges Dam on Yangtze River flow and river interaction with Poyang Lake, China: 2003-2008," Journal of Hydrology, vol. 416417, pp. 19-27, 2012.

[18] G. L. Wei, Z. F. Yang, B. Cui et al., "Impact of dam construction on water quality and water self-purification capacity of the Lancang River, China," Water Resources Management, vol. 23, no. 9, pp. 1763-1780, 2009.

[19] M. Wiatkowski, "Influence of słup dam reservoir on flow and quality of water in the Nysa Szalona river," Polish Journal of Environmental Studies, vol. 20, no. 2, pp. 469-478, 2011.

[20] S. F. Sim, T. Y. Ling, L. Nyanti, N. Gerunsin, Y. E. Wong, and L. P. Kho, "Assessment of heavy metals in water, sediment, and fishes of a large tropical hydroelectric dam in Sarawak, Malaysia," Journal of Chemistry, vol. 2016, Article ID 8923183, 10 pages, 2016.
[21] D. Jenkins, J. J. Connors, and A. E. Greenberg, Standard Methods for the Examination of Water and Wastewater, American Public Health Association, Washington, DC, USA, 21st edition, 2005.

[22] Hach, Hach Water Analysis Handbook, Hach Company, Loveland, Colo, USA, 2015.

[23] Department of Environment, Malaysia Environmental Quality Report 2014, Department of Environment, Kuala Lumpur, Malaysia, 2015.

[24] S.-C. Chen, X.-Q. Liu, W. Jiang et al., "Effects of total dissolved gas supersaturated water on lethality and catalase activity of Chinese sucker (Myxocyprinus asiaticus Bleeker)," Journal of Zhejiang University: Science B, vol. 13, no. 10, pp. 791-796, 2012.

[25] R. Liang, B. Li, K. Li, and Y. Tuo, "Effect of total dissolved gas supersaturated water on early life of David's schizothoracin (Schizothorax davidi)," Journal of Zhejiang University. Science B, vol. 140, no. 7, pp. 632-639, 2013.

[26] T. Y. Ling, D. P. Debbie, N. Lee, I. Norhadi, and J. J. E. Justin, "Water quality at Batang Ai hydroelectric reservoir (Sarawak, Malaysia) and implications for aquaculture," International Journal of Applied Sciencce and Technology, vol. 2, no. 6, pp. 23-30, 2012.

[27] J. Nix, "Spatial and temporal distribution of sulfide and reduced metals in the tailwater of Narrows dam (Lake Greeson), Arkansas," Tech. Rep. E-86-14, US Army Corps of Engineers, Washington, DC, USA, 1986. 

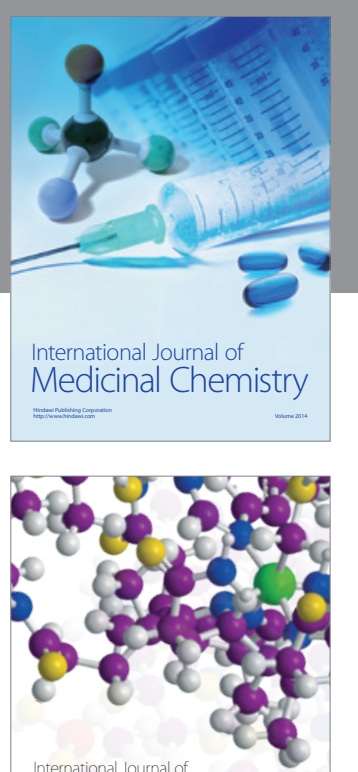

Carbohydrate Chemistry

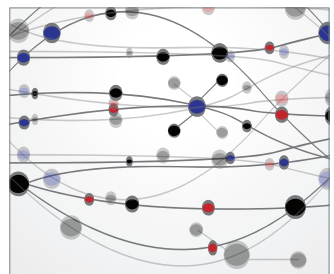

The Scientific World Journal
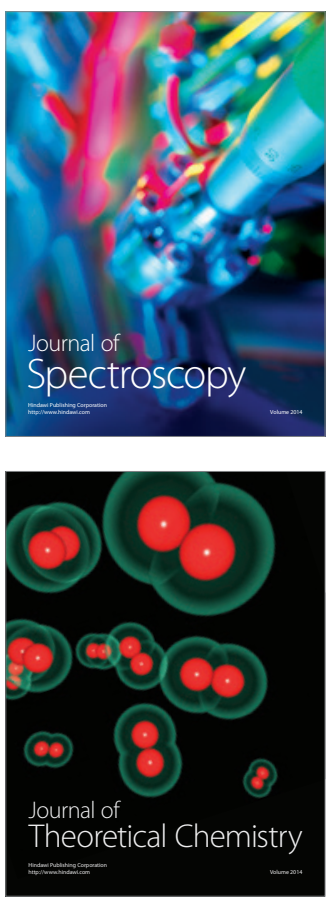
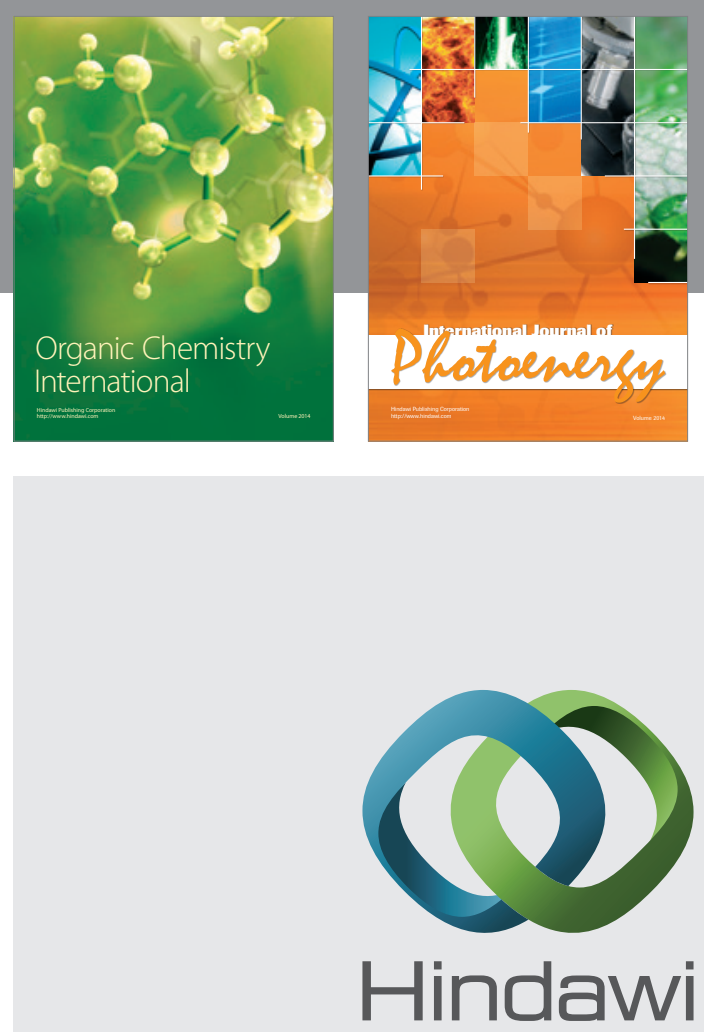

Submit your manuscripts at

http://www.hindawi.com

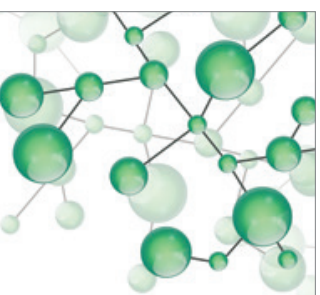

International Journal of

Inorganic Chemistry

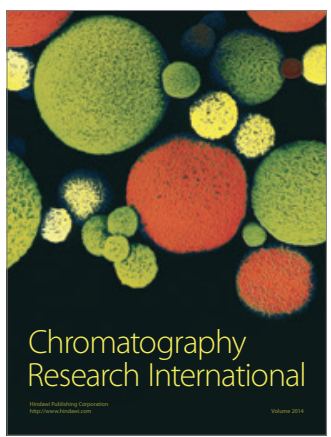

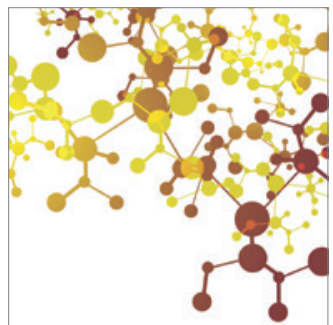

Applied Chemistry
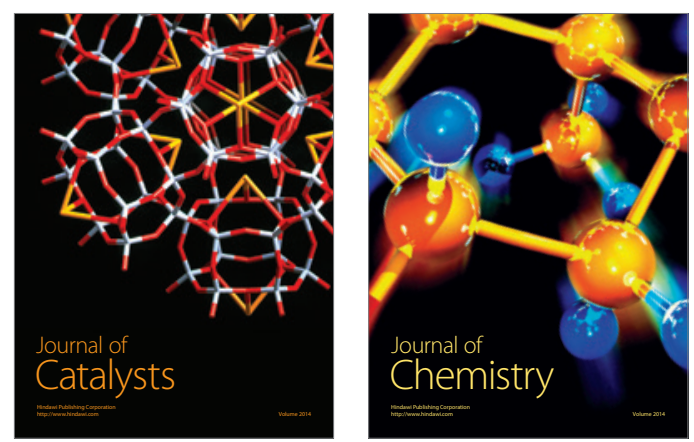
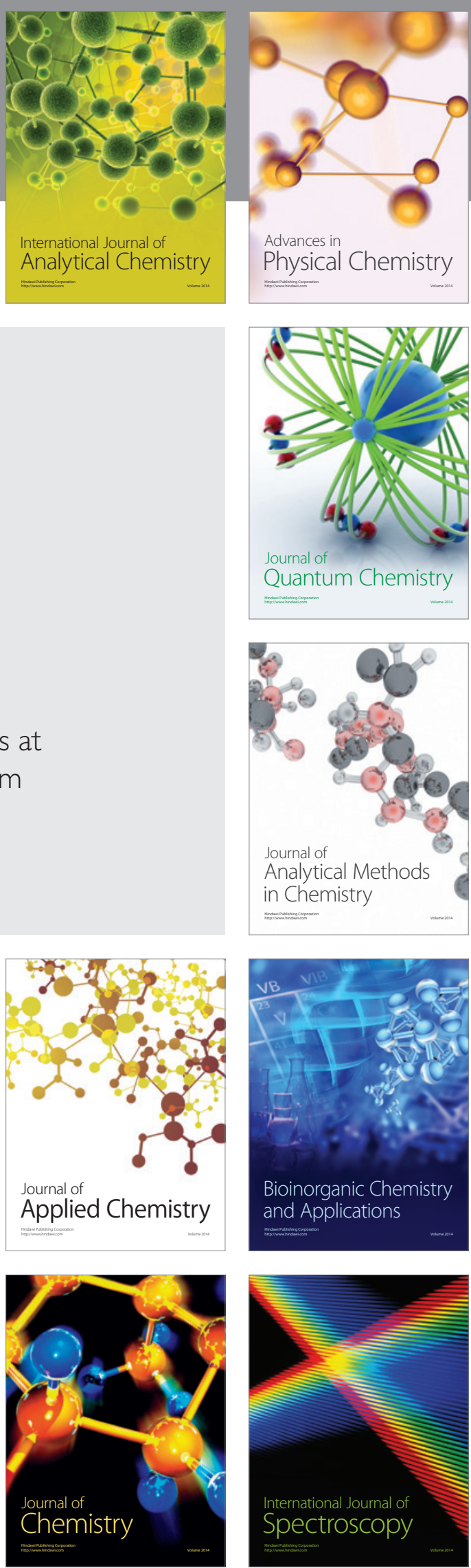